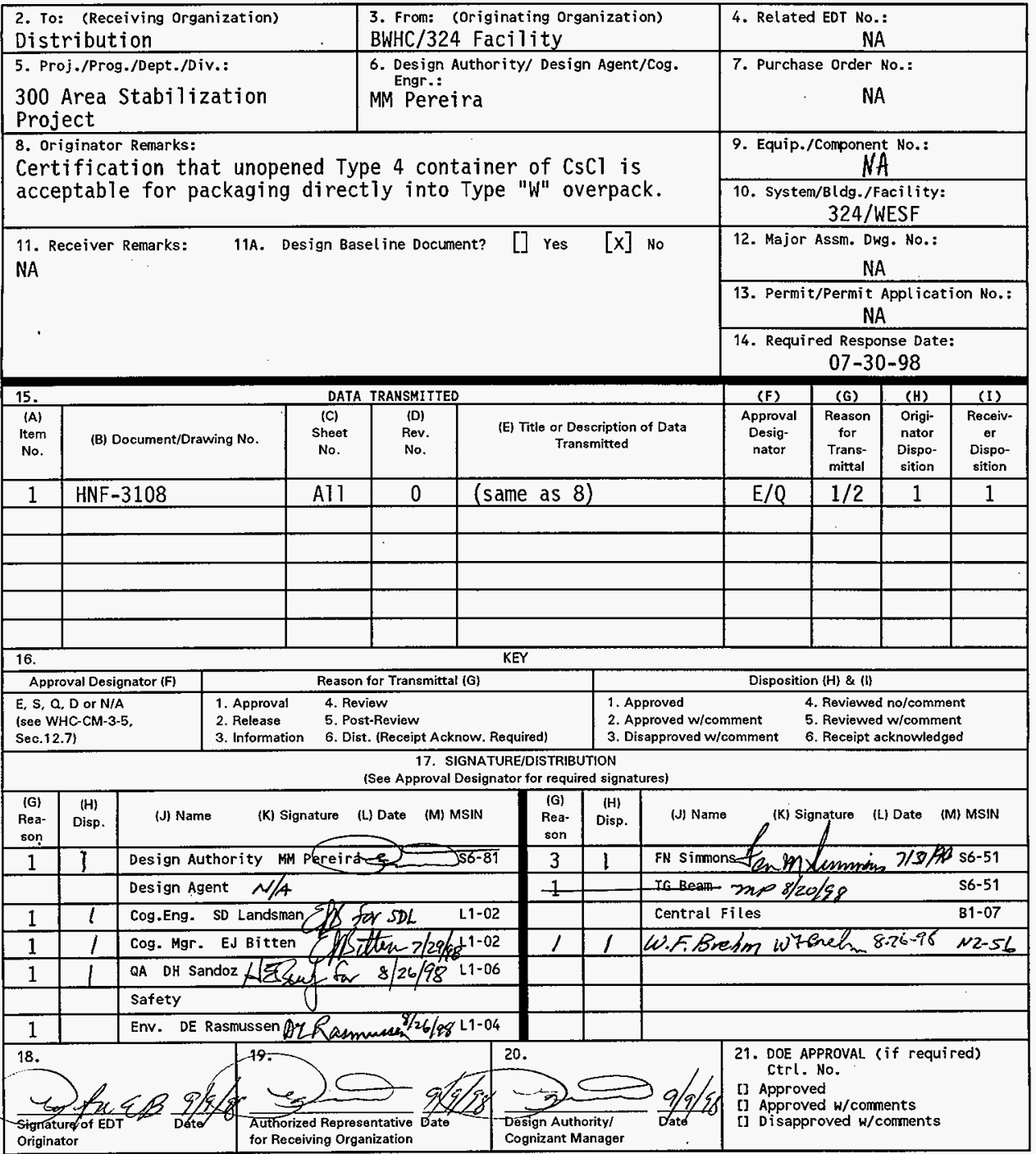

BD $-7400-172-2(05 / 96)$ GEF097 


\section{L Stainless Steel Resistance to Cesium Chloride}

\section{E. Graves}

BWHC, Richland, WA 99352

U.S. Department of Energy Contract DE-AC06-96RL13200

EDT/ECN: 625234

Org Code: 19350

B\&R Code: EW7050000
UC: 2000

Charge Code: K4C21

Tota1 Pages: $6.1 \underset{8-27}{\mathrm{c}}-98$

Key Words: Cesium Chloride, Type 4 Canister, WESF Inner Capsule

Abstract: Certification that unopened Type 4 container of $\mathrm{CsCl}$ is acceptable for packaging directly into Type "W" overpack.

TRADEMARK DISCLAIMER. Reference herein to any specific comercial product, process, or service by trade name, trademark, manufacturer, or otherwise, does not necessarily constitute or imply its endorsement, recommendation, or favoring by the United States Government or any agency thereof or its contractors or subcontractors.

Printed in the United States of America. To obtain copies of this document, contact: Document Control Services, P.0. Box 950, Mailstop H6-08, Richland WA 99352, Phone (509) 372-2420; Fax (509) 376-4989.
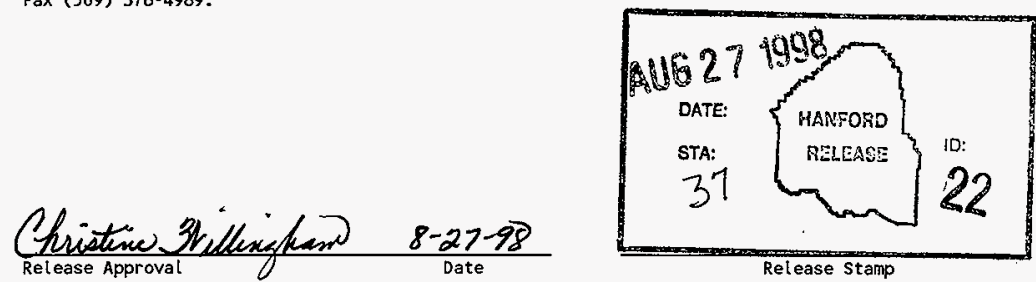
HNF-3108

Rev. 0

\section{L STAINLESS STEEL RESISTANCE TO CESIUM CHLORIDE}

August 1998

Prepared by .

C. E. Graves

Fluor Daniel Northwest

Richland, Washington 
HNF-3108

Rev. 0

TABLE OF CONTENTS

$\underline{\text { Page }}$

1.0 INTRODUCTION

2.0 316L SS CORROSION RESISTANCE TO CsCl

$\begin{array}{ll}3.0 \text { DISCUSSION } & 2\end{array}$

4.0 CONCLUSIONS 3

5.0 REFERENCES

ABBREVIATIONS / ACRONYMS

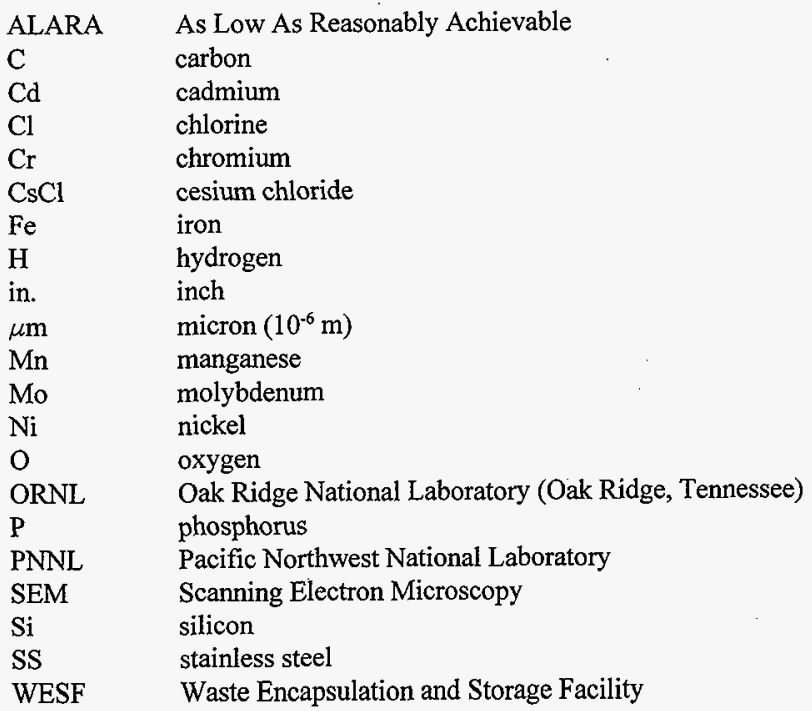


HNF-3 108

Rev. 0

\section{L STAINLESS STEEL RESISTANCE TO CESIUM CHLORIDE}

\subsection{INTRODUCTION}

B\&W Hanford Company have two Oak Ridge National Laboratory (ORNL) Type 4 canisters filled with cesium chloride $(\mathrm{CsCl})$ originally produced at WESF (Waste Encapsulation and Storage Facility). These canisters are constructed of 304L stainless steel per drawing ORNL 970-294. Instead of removing the $\mathrm{CsCl}$ from the Type 4 canisters and repacking into an Inner Capsule, it is intended (for ALARA, schedule and cost purposes) that the Type 4 canisters be decontaminated (scrubbed) and placed [whole] inside a Type "W" overpack. The overpack is constructed from $316 \mathrm{~L}$ stainless steel.

Several tests have been run by Pacific Northwest National Laboratory (PNNL) over the years documenting the corrosion compatibility of 316L SS with $\mathrm{CsCl}$ (Bryan 1989 and Fullam 1972). However, no information for 304L SS compatibility is readily available. This document estimates the corrosion resistance of $304 \mathrm{~L}$ stainless steel in a WESF $\mathrm{CsCl}$ environment as it compares with that of $316 \mathrm{~L}$ stainless steel.

\subsection{L SS CORROSION RESISTANCE TO CsCl}

Fullam (1972) extrapolated his short-term compatibility data to indicate the attack of $316 \mathrm{~L}$ SS by $\mathrm{CsCl}$ waste at $400^{\circ} \mathrm{C}\left(750^{\circ} \mathrm{F}\right)$ over a 600 year period should not exceed $635 \mu \mathrm{m}(0.025$ in.). Visual inspection of photomicrographs showed little evidence of intergranular penetration but some pitting and subsurface void formation was present. Carbide precipitation was evident near the sample surface and along grain boundaries. The extent of the carbide precipitation increased with time at temperature. ${ }^{\dagger}$

Bryan (1989) conducted long term (6 year) tests with WESF canisters to try to obtain more reliable estimates on the long-term corrosion resistance of $316 \mathrm{~L} \mathrm{SS}$ to $\mathrm{CsCl}$ at $450{ }^{\circ} \mathrm{C}\left(840^{\circ} \mathrm{F}\right)$. His examination of photomicrographs also showed subsurface void formation and carbide precipitation (again, the number of precipitates increased with time at temperature).

\footnotetext{
t The presence of carbide precipitates reduces the corrosion resistance of the stainless steel at the grain boundaries.
} 
Thermodynamic calculations by Bryan (1989) indicate that pure $\mathrm{CsCl}$ should not react with $316 \mathrm{~L} \mathrm{SS}$ at the test temperatures, however, certain impurities in the $\mathrm{CsCl}$ could react with the $316 \mathrm{~L}$ SS. Possible impurities that could react include the less stable chlorides, such as $\mathrm{FeCl}_{2}$, $\mathrm{NiCl}_{2}$, and $\mathrm{CdCl}_{2}$, and the less stable oxides such as $\mathrm{Fe}_{3} \mathrm{O}_{4}, \mathrm{NiO}$ and $\mathrm{H}_{2} \mathrm{O}$. In trying to identify the reactions, samples were analyzed by SEM (scanning electron microscopy). Bryan concludes that the only reaction that could be identified with any certainty was the leaching of $\mathrm{Mn}$ from the $316 \mathrm{~L} \mathrm{SS}$ in the reaction zone.

If impurities in the $\mathrm{CsCl}$ are the principal cause of corrosion, the extent of reaction should be limited by the amount of impurities available to react with the $316 \mathrm{~L} \mathrm{SS}$ components. The corrosion rate would initially be high and then decrease with time as the impurities are consumed. The rate controlling step for each reaction is likely to be the diffusion of the impurity reactant from the bulk $\mathrm{CsCl}$ to the metal/ $\mathrm{CsCl}$ interface (Bryan 1989). If a liquid phase is present, it could accelerate this diffusion.

Bryan tabulated the effect of impurities on the phase transition temperature and melting point of $\mathrm{CsCl}$ (1989, pg A.17). The impurity with the greatest effect is iron. For a $\mathrm{CsCl}+3 \% \mathrm{FeCl}_{3}$ system the minimum melting point is $270^{\circ} \mathrm{C}\left(520^{\circ} \mathrm{F}\right)$; melting began before a phase transition temperature could be detected. This falls well below the test temperature, thus a liquid phase would be present.

When pure molten $\mathrm{CsCl}$ is poured into a $316 \mathrm{~L}$ SS capsule and allowed to solidify, the solid mass does not adhere to the wall (void spaces are formed as the mixture cools and collapses). Bryan (1989) hypothesizes that impurities cause some of the $\mathrm{CsCl}$ to adhere to the capsule wall. Thus, corrosion in areas where there is no $\mathrm{CsCl} /$ steel contact should be much less than in contact areas. If samples were [inadvertently] taken in areas of no contact, this theory could help to explain some of the data scatter in previous studies.

\subsection{DISCUSSION}

304L and 316L SS are both austenitic stainless steels with similar compositions (see Table 1). The lower carbon values (versus 304 and 316 ) improve corrosion resistance in welded structures (ASM 1990). The addition of molybdenum in 316L SS increases the steel's resistance to the initiation of pitting and crevice corrosion (ASM 1990). Both of these alloys are used extensively in the nuclear industry.

Table 1: Stainless Steel Compositions (ASM 1990, pg 843)

\begin{tabular}{|c|c|c|c|c|c|c|c|c|}
\hline \multirow{2}{*}{ Type } & \multicolumn{7}{|c|}{ Composition, wt.\% (Remainder is Fe) } \\
\cline { 2 - 9 } & $\mathbf{C}$ & $\mathbf{M n}$ & $\mathbf{S i}$ & $\mathbf{C r}$ & $\mathbf{N i}$ & $\mathbf{P}$ & $\mathbf{S}$ & Mo \\
\hline 304L & 0.03 & 2.00 & 1.00 & $18-20$ & $8-12$ & 0.045 & 0.03 & $\ldots$ \\
\hline
\end{tabular}


HNF-3108

Rev. 0

\begin{tabular}{|l|l|l|l|l|l|l|l|l|}
\hline $316 \mathrm{~L}$ & 0.03 & 2.00 & 1.00 & $16-18$ & $10-14$ & 0.045 & 0.03 & $2.00-3.00$ \\
\hline
\end{tabular}

With the great similarity in composition between the 304L and 316L SS (equal amounts of $\mathrm{Mn}$ and $\mathrm{Si}$, near equal amounts of $\mathrm{Cr}$ and $\mathrm{Ni}$ ), the potential corrosion reactions with the $\mathrm{CsCl}$ would also be similar (leaching of manganese in the reaction area). As subsurface void formation and carbide precipitation are the predominate corrosion features observed, the addition of molybdenum to the $316 \mathrm{~L}$ [to reduce pitting and crevice corrosion] does not seem to provide an extra advantage to corrosion resistance.

During its stay at $\mathrm{ORNL}$, the $\mathrm{CsCl}$ was water-washed which lowered the impurity levels (Landsman 1998), thus lowering the amount of available corrosion reactants. The lowering of iron content by washing (to $<0.005 \%$ ) would also minimize the potential for any liquid phase to form and decrease impurity diffusion to the surface. Water storage of this WESF canister would greatly reduce the system $(\mathrm{CsCl} /$ steel) temperature, which in turn would further lower corrosion rates.

Corrosion on the exterior of the Type 4 canister due to any remaining $\mathrm{CsCl}$ after decontamination would be minimal, as any impurity would be quickly consumed. Lastly, as no water or moisture is expected between the Type 4 canister and the WESF overpack, any possible galvanic corrosion between the $304 \mathrm{~L}$ and $316 \mathrm{~L} \mathrm{SS}$ is avoided. As these two alloys are only slightly separated on the galvanic series (ASM 1990, pg 557), galvanic corrosion would be unlikely even with water present.

\subsection{CONCLUSIONS}

With much lower impurity levels in the water-washed ORNL $\mathrm{CsCl}$ and a similar steel composition, the $304 \mathrm{~L}$ stainless steel is expected to exhibit equal to or better corrosion resistance than the $316 \mathrm{~L}$ stainless steel in this application. Thus, packing of the Type 4 canisters within the WESF overpack is judged acceptable.

\subsection{REFERENCES}

ASM, 1990, "Stainless Steels" in Metals Handbook, Volume 1 - Properties and Selection: Irons, Steels, and High-Performance Alloys, 10th Edition, American Society for Metals, Metals Park, Ohio.

Bryan, G. H., 1989, Cesium Chloride Compatibility Testing Program--Final Report, PNL-7133, Pacific Northwest Laboratory, Richland, Washington.

Fullam, H. T., 1972, Compatibility of Cesium Chloride and Strontium Fluoride With Containment Materials, BNWL-1673, Pacific Northwest Laboratory, Richland, Washington. 
HNF-3108

Rev. 0

Landsman, S. D., 1998, Certification That CsCl Powder and Pellet Materials Meet WESF Acceptance Criteria, HNF-2928, Rev. 0, B\&W Hanford Company, Richland, Washington.

ORNL, "Powder Shipping Cans - Type 4 (SK-365-B)", ORNL Dwg \#970-294, Oak Ridge National Laboratory, Oak Ridge, Tennessee. 


\section{DISTRIBUTION SHEET}

\begin{tabular}{|c|c|c|c|c|c|}
\hline \multirow{2}{*}{$\begin{array}{l}\text { To } \\
\text { Distribution }\end{array}$} & \multirow{2}{*}{\multicolumn{3}{|c|}{$\begin{array}{l}\text { From } \\
\text { BWHC/324 Facility }\end{array}$}} & \multicolumn{2}{|c|}{ Page 1 of 1} \\
\hline & & & & \multicolumn{2}{|c|}{ Date $07 / 28 / 98$} \\
\hline \multirow{2}{*}{\multicolumn{4}{|c|}{$\begin{array}{l}\text { Project Title/Work Order } \\
304 \mathrm{~L} \text { Stainless Steel Resistance to Cesium Chloride } \\
\text { HNF-3108, Rev. 0 }\end{array}$}} & \multicolumn{2}{|c|}{ EDT No. 625234} \\
\hline & & & & \multicolumn{2}{|c|}{ ECN No. } \\
\hline Name & MSIN & $\begin{array}{l}\text { Text } \\
\text { With All } \\
\text { Attach. }\end{array}$ & Text Only & $\begin{array}{l}\text { Attach./ } \\
\text { Appendix } \\
\text { Only }\end{array}$ & $\begin{array}{l}\text { EDT/ECN } \\
\text { Only }\end{array}$ \\
\hline $\begin{array}{l}\text { TG Beam } \\
\text { EJ Bitten } \\
\text { SD Landsman } \\
\text { MM Pereira } \\
\text { DE Rasmussen } \\
\text { DH Sandoz } \\
\text { FN Simmons } \\
\text { Central Files }\end{array}$ & $\begin{array}{l}\text { S6-51 } \\
\text { L1-02 } \\
\text { L1-02 } \\
\text { S6-81 } \\
\text { L1-04 } \\
\text { L1-06 } \\
\text { S6-51 } \\
\text { B } 1-07\end{array}$ & & & & \\
\hline
\end{tabular}

